International Research Journal of Management, IT \& Social Sciences
Available online at https://sloap.org/journals/index.php/irjmis/
Vol. 7 No. 3, May 2020, pages: 137-143
ISSN: 2395-7492
https://doi.org/10.21744/irjmis.v7n3.934

\title{
Safe Haven Investment During Turbulent Conditions in Indonesia and Philippines Capital Market
}

\author{
A.A. Gde Ari Widhiasmana Pemayun ${ }^{a}$ \\ Gerianta Wirawan Yasa ${ }^{b}$
}

Article history:

Submitted: 09 March 2020

Revised: 18 April 2020

Accepted: 27 May 2020

\section{Keywords:}

capital market;

gold;

government bonds;

silver;

\begin{abstract}
Haven investment is a safe and profitable asset for investors during turbulent capital market conditions. Investors tend to divert investment in shares owned to safe-haven assets to secure investment value during the decline in value on the stock market. This study aims to obtain empirical evidence related to the ability of gold as a safe-haven investment in the State of Indonesia and the ability of gold as a safe-haven investment in the Philippines. The data used in this study is a daily return from the period January 1, 2018, to February 20, 2020. Data analysis techniques used in this study use the Augmented DickeyFuller (ADF) stationary test and the quantile regression analysis test with a quintile rate of $50 \%, 40 \%, 30 \%, 20 \%$, and $10 \%$. The results show that gold is a haven investment in Indonesia. Gold is a haven investment in the Philippines.
\end{abstract}

International research journal of management, IT and social sciences $@ 2020$.

This is an open access article under the CC BY-NC-ND license (https://creativecommons.org/licenses/by-nc-nd/4.0/).

\section{Corresponding author:}

Ari Widhiasmana Pemayun,

Faculty of Economic and Business Udayana University, Denpasar, Indonesia.

Email address: ariwpemayun@gmail.com

Faculty of Economic and Business Udayana University, Denpasar, Indonesia

Faculty of Economic and Business Udayana University, Denpasar, Indonesia 


\section{Introduction}

Investors make investments to get returns or dividends from their investments. Investment in shares is one investment with a high level of risk but can provide high returns, also known as high-risk high returns. Return and risk have a positive relationship (Hartono, 2008). The relationship between risk and return needs to be considered by investors to manage the existing risk to minimize the number of investment losses. Investment risk will increase during turbulent times of uncertainty in the capital market.

Turbulent conditions that occur today are caused by a trade war between the United States and China that began in January 2018 until a peace agreement was reached by the two countries on February 15, 2020. The trade war was preceded by an entry tariff policy for imported Chinese products such as solar panels, solar panels, and washing machines by the President of the United States in January 2018. The trade war between the two countries resulted in changes in import tariff policies and investment restrictions between the two countries, which also affected globally. The trade war between the two countries has a large turbulent economic impact because the United States is a Superpower and China is one of the developed countries.

The trade war caused a slowdown in global economic growth. Based on the WEO (World Economic Outlook) report by the IMF (International Monetary Fund) there has been a slowdown in global economic growth in 2018 and 2019. Slowing global economic growth in 2019 by 3\% which is the lowest economic growth since the crisis in 20082009 (International Monetary Fund, 2019). Slowing economic growth is certainly hampering business processes, the stock market, and improving turbulent conditions in the market.

Turbulent conditions will increase investor anxiety in investing in the stock market. Investors will try to find investment alternatives that are considered safe. The motivation of investors to look for safe-haven assets is to minimize risk exposure by having better quality assets during a severe market downturn (Bulut \& Rizvanoghlu, 2019). Transferring assets to other assets that are safer and more liquid can stop the decline in the value of assets owned by investors (Agyei-Ampomah et al., 2014). So there is a tendency of investment run away from the stock market to safehaven assets during turbulent conditions. This is in line with the portfolio theory by Markowitz. Markowitz (1952), suggests portfolio theory which explains that in general risk can be reduced by combining several single securities into a portfolio. The main requirement to reduce risk is that returns from securities do not correlate positively and perfectly (Hartono, 2008). Investors can reduce portfolio risk by adding safe-haven assets to their portfolios.

Haven investment is an asset that has no correlation or is negatively correlated with other assets or portfolios when economic shocks occur (Baur \& Lucey, 2010; Ratnaningsih \& Widanaputra, 2019). This means that assets in the safehaven investment category will not have the same movements as other assets during economic shocks (Ciner $e t$ al., 2013), which in this case is the value of the stock index. This has made safe-haven assets a safe choice for investors during turbulent times. Various assets are considered capable of becoming a haven investment, one of which is gold.

The results of the study by Ghazali et al. (2015); Bekiros et al. (2017), who discovered that gold could not play a role as a safe-haven investment. Different results were found in the results of research by Chen \& Wang (2019); Hunt et al. (2018); Boubaker et al. (2020); Robiyanto (2018); Gürgün \& Ünalmiş (2014), who discovered that gold could be a haven investment asset. Empirical results related to the ability of gold as a haven are still diverse. There are still inconsistencies in the results of research related to the ability of gold as a safe-haven asset. So it is important to do a re-test related to the ability of gold as a safe-haven investment in Indonesia and the Philippines.

Indonesia and the Philippines were chosen as research locations due to the limited empirical results related to the ability of gold as a safe-haven investment in both countries, both countries have a stock index value that is close to when compared to other countries, besides, Indonesia and the Philippines are members of ASEAN, so it is considered to deserve to be compared.

\section{Portfolio Theory}

Portfolio theory is an investment approach initiated by Markowitz (1952). The portfolio theory deals with investor estimates of risk and returns expectations that are measured statistically to create an investment portfolio. The portfolio theory assumes that rational investors refuse to increase risk without the expected increase in returns. The relationship between risks received and expected returns are the basis for modern lending and investment decisions. The greater the risk of an investment or loan, the greater the desired rate of return to cover the risk. Management of investment funds in this way will form an optimal portfolio. Markowitz describes how to combine assets into optimal portfolio diversification. Portfolio risk can be reduced by adding the number of types of assets to a portfolio that has a different level of risk and does not have a perfect positive correlation. The basis of the Markowitz portfolio model is to provide 
input to investors to minimize risk and maximize expected returns on each investment decision. Diversification can be done by selecting stocks from different sectors or adding other asset classes to reduce total portfolio risk.

\section{Signaling Theory}

Signal theory originated from Akerlof (1978), entitled "The Market for Lemons" which introduced the term asymmetric information. Akerlof found that there were differences in the amount of information held between the buyer and seller, which in this case was between the company and the investor. Investors generally have less information than companies. Companies tend to provide information (signals) to investors to increase investor understanding and trust regarding company conditions. Complete, relevant, accurate, and timely information is needed by investors in making decisions. Signal theory in this study explains that in turbulent conditions in the capital market there will be many negative signals that cause concern for stock investors to invest. Concerned stock investors will tend to shift their investment to safe-haven investment to secure the value of their investments.

\section{Safe Haven Investment}

Kaul \& Sapp (2006), define haven as an attractive asset for investors when market conditions are experiencing uncertainty. The broad definition of a safe haven is an asset with low market risk and high liquidity that is chosen when investors feel fear of market losses (Flavin et al., 2014). During turbulence in the capital market when prices of other instruments fall, investors will try to shift their investment from one asset class to a safer and more liquid asset class. This action is important so that investors can stop the decline in the value of their investments (Agyei-Ampomah et al., 2014).

Baur \& Lucey (2010), define haven investment more quantitatively, stating that haven investment is an asset that has zero or negative correlation with other assets or portfolios during turbulent periods in the financial markets. Haven investment is different from hedging, where hedging is an asset that has no correlation or is negatively correlated with other assets or portfolios in normal market conditions (Baur \& Lucey, 2010). Hedging assets generally have a positive correlation when the market is shaking and negatively correlated when normal market conditions (Robiyanto et al., 2017). Haven investment is only negatively correlated or uncorrelated during economic shocks and does not apply to normal conditions and long periods. This means that the value of safe-haven investment assets tends to move up or stable when stock prices in the capital market decline or turbulent.

\section{Gold as a haven investment in Indonesia and the Philippines}

For centuries gold was used as a universal payment and a means of accumulating wealth as well as financial assets (Putra et al., 2018). Gold is seen as a financial asset because gold has been used as a financial or economic standard, foreign exchange reserves, and even the main payment instruments in several countries (Dee et al., 2013). Gold can protect the portfolio value from extreme currency shocks, provides diversification benefits, is resistant to inflationary shocks, and stock price declines (Reboredo \& Rivera-Castro, 2014; Arouri et al., 2015). Gold has a long history as a haven investment. Gold prices even tend to move against the conditions of the capital market, this makes gold a safe alternative investment for investors (Wang, 2012). Following the definition of safe-haven investment by Baur \& Lucey (2010), safe-haven investment is an asset that has no correlation or is negatively correlated with other assets or portfolios when economic shocks occur so that gold is considered to have the potential to be a haven investment.

The results of the study by Chen \& Wang (2019); Hunt et al. (2018); Boubaker et al. (2020), found that gold could be a haven investment asset. Specifically, the results of research by Robiyanto (2018), found that gold can be a haven investment in the State of Indonesia. Gürgün \& Ünalmiş (2014), found that gold could be a haven asset in the Philippines. Based on this explanation, several hypotheses are formulated as follows.

Hla: Gold can be a safe haven investment in Indonesia

$H 1 b$ : Gold can be a safe haven investment in the Philippines.

\section{Materials and Methods}

The study was conducted by observing the daily return value of gold in Indonesia in Rupiah, gold in the Philippines in PESO, shares in Indonesia represented by the IHSG, shares in the Philippines represented by PSEi. The price of gold

Pemayun, A. G. A. W., \& Yasa, G. W. (2020). Safe haven investment during turbulent conditions in Indonesia and Philippines capital market. International Research Journal of Management, IT and Social Sciences, 7(3), 137-143. https://doi.org/10.21744/irjmis.v7n3.934 
used is the price of gold per gram. The research observation period starts from January 2018-20 February 2020 with a total of 521 trading days. Stock returns are calculated by using the closing value of the stock closing price so that data stability testing is needed. Data stability testing uses the Augmented Dickey-Fuller (ADF) Test developed by Dickey \& Fuller (1979). After the data is stable, a quantile regression test is performed with Eviews. Quantile regression testing uses quantile levels of $50 \%, 40 \%, 30 \%, 20 \%$ and $10 \%$

Quantile regression testing for gold in the Indonesian capital market based on the following formula:

$\mathbf{R}_{\text {GoldIDR,t }}=\alpha+\beta_{1} \mathbf{R}_{\text {IHSG }(Q 50 \%, 40 \%, 30 \%, 20 \%, 10 \%)}+\varepsilon$

Quantile regression testing for gold in the Philippine capital market based on the following formula:

$\operatorname{R}_{\text {GoldPESO, } \mathrm{t}}=\alpha+\boldsymbol{\beta}_{1} \operatorname{RPSEi}(\mathrm{Q} 50 \%, 40 \%, 30 \%, 20 \%, 10 \%)+\varepsilon$.

Information:

Gold IDR = Gold denominated in Indonesian Dollar

Gold PESO = Gold denominated in PESO

IHSG $\quad=$ Indonesian State stock index

PSEi $\quad=$ Philippine State stock index.

\section{Results and Discussions}

Augmented Dickey-Fuller test

Table 1

Augmented Dickey-Fuller stationary test results

\begin{tabular}{|c|c|c|c|c|c|c|}
\hline \multirow{2}{*}{ No } & \multirow{2}{*}{ Variable } & \multirow{2}{*}{$\mathrm{t}$-Statistic } & \multicolumn{3}{|c|}{ Critical Point } & \multirow{2}{*}{ Probability } \\
\hline & & & $1 \%$ Level & $5 \%$ Level & $10 \%$ Level & \\
\hline 1 & JCI & -22.05622 & -3.442722 & -2.866889 & -2.56968 & $0 *$ \\
\hline 2 & PSEi & -22.93517 & -3.442722 & -2.866889 & -2.56968 & $0 *$ \\
\hline 3 & Gold IDR & -4.327895 & -3.442945 & -2.866988 & -2.569733 & $0.0004 *$ \\
\hline 4 & Gold_PESO & -24.17743 & -3.442722 & -2.866889 & -2.56968 & $0 *$ \\
\hline
\end{tabular}

* Significant at the 1\% level

Secondary Data, 2020

The test results show that all variables used in the study passed the Augmented Dickey-Fuller test, where the t-statistic value is smaller than the critical point value and the probability value is smaller than $\alpha(0.05)$. All data shows that the root unit is not present in the sample data in sequence, the data is said to be stationary and can be used in research.

\section{Hypothesis Testing}

Table 2 shows the results of the quantile regression test with a significance level of $10 \%$ for the Indonesian capital market.

Table 2

Quantile regression test results for the Indonesian and Philippine capital markets

\begin{tabular}{llllll}
\hline & \multicolumn{5}{c}{ quantile } \\
\cline { 2 - 6 } & 0.5 & 0.4 & 0.3 & 0.2 & 0.1 \\
\hline C & 0.000527 & -0.001254 & -0.003362 & -0.005453 & -0.008393 \\
Gold IDR & -0.06099 & -0.073166 & $-0.099165^{* *}$ & -0.00065 & -0.006424
\end{tabular}




\begin{tabular}{llllll}
\hline C & $7.90 \mathrm{E}-05$ & -0.001463 & -0.003091 & -0.005276 & -0.008327 \\
Gold PESO & $-0.076638^{* *}$ & $-0.071937 *$ & $-0.053538^{*}$ & -0.022573 & 0.015074 \\
\hline
\end{tabular}

Secondary Data, 2020

The results of the analysis using quantile regression showed that the JCI return had a significant effect on the return of gold denominated in Rupiah at the $30 \%$ quantile level (Prob Quasi-LR $0.032<0.10$ ) and had a negative correlation coefficient. JCI return does not significantly influence the return of gold in Rupiah at the quantile level of $50 \%, 40 \%$, $20 \%, 10 \%$ (Prob Quasi-LR> 0.10). Gold is a haven investment in Indonesia at a 30\% quantile level because it has a significant influence and a negative correlation value, this is following the definition of haven by Baur \& Lucey (2010), which states that safe-haven assets are not correlated or negatively correlated with other assets. Gold is a haven investment in turbulent capital market conditions and as turbulent conditions increase, the ability of gold as a haven will disappear. In extreme turbulent conditions, investors in Indonesia no longer see gold as a haven and choose other safe-haven assets. The results of this study indicate that gold can be a haven investment in Indonesia. The results of this study support hypothesis 1a (H1a). The results of this study support previous research by Chen \& Wang (2019); Hunt et al. (2018), Boubaker et al. (2020); Robiyanto (2018), who discovered that gold is a haven investment.

The results of the analysis with quantile regression for the Philippine capital market show that PSEi return has a significant effect on gold return in PESO at the quantile level of 50\%, 40\%, and 30\% (Prob Quasi-LR <0.10) and has a negative correlation coefficient. PSEi return has no significant effect on gold returns in PESO at the quantile level of $20 \%$ and 10\% (Prob Quasi-LR> 0.10). Gold is a haven investment in the Philippines at a quintile of 50\%, 40\%, and $30 \%$ because it has a significant influence and a negative correlation value, this is following the definition of haven by Baur \& Lucey (2010), which states that safe-haven assets are not correlated or negatively correlated with other assets. Gold is a haven investment in turbulent capital market conditions and as turbulent conditions increase, the ability of gold as a haven will disappear. In extreme turbulent conditions, investors in the Philippines will look for an alternative safe-haven investment other than gold, so that gold is no longer a haven investment in extremely turbulent conditions. The results of this study indicate that gold can be a haven investment in the Philippines. The results of this study support the hypothesis $1 \mathrm{~b}(\mathrm{H} 1 \mathrm{~b})$. The results of this study support previous research by Chen \& Wang (2019); Hunt $e t$ al. (2018); Boubaker et al. (2020); Gürgün \& Ünalmiş (2014), who discovered that gold is a haven investment.

\section{Conclusion}

Based on the results of the analysis it can be concluded that (1) gold can be a haven investment in the State of Indonesia, (2) gold can be a haven investment in the Philippines. Investors in Indonesia and the Philippines should add gold to the portfolio when the capital market experiences turbulent conditions. Gold that has a negative correlation with stocks will be able to minimize the decline in the value of the portfolio. When turbulent market conditions improve, investors are advised to switch their investments to other safe-haven assets. This is due to the movement of gold returns tend to move in the direction of stock returns, so that in extremely turbulent conditions gold is no longer able to become a haven investment. Based on the analysis several suggestions can be given for further research. This study is limited to testing only at the quantile level of $50 \%, 40 \%, 30 \%, 20 \%, 10 \%$, it is recommended that in the future it can use lower quantile levels such as $5 \%, 2.5 \%$, and $1 \%$. This research is limited to only testing the gold assets, in the future can use other assets that are considered capable of becoming a haven investment.

\section{Conflict of interest statement}

The authors declared that they have no competing interests.

Statement of authorship

The authors have a responsibility for the conception and design of the study. The authors have approved the final article.

\section{Acknowledgments}

We are grateful to two anonymous reviewers for their valuable comments on the earlier version of this paper.

Pemayun, A. G. A. W., \& Yasa, G. W. (2020). Safe haven investment during turbulent conditions in Indonesia and Philippines capital market. International Research Journal of Management, IT and Social Sciences, 7(3), 137-143. https://doi.org/10.21744/irjmis.v7n3.934 


\section{References}

Agyei-Ampomah, S., Gounopoulos, D., \& Mazouz, K. (2014). Does gold offer a better protection against losses in sovereign debt bonds than other metals?. Journal of Banking \& Finance, 40, 507-521. https://doi.org/10.1016/j.jbankfin.2013.11.014

Akerlof, G. A. (1978). The market for "lemons": Quality uncertainty and the market mechanism. In Uncertainty in economics (pp. 235-251). Academic Press. https://doi.org/10.1016/B978-0-12-214850-7.50022-X

Arouri, M. E. H., Lahiani, A., \& Nguyen, D. K. (2015). World gold prices and stock returns in China: insights for hedging and diversification strategies. Economic Modelling, 44, 273-282. https://doi.org/10.1016/j.econmod.2014.10.030

Baur, D. G., \& Lucey, B. M. (2010). Is gold a hedge or a safe haven? An analysis of stocks, bonds and gold. Financial Review, 45(2), 217-229. https://doi.org/10.1111/j.1540-6288.2010.00244.x

Bekiros, S., Boubaker, S., Nguyen, D. K., \& Uddin, G. S. (2017). Black swan events and safe havens: The role of gold in globally integrated emerging markets. Journal of International Money and Finance, 73, 317-334. https://doi.org/10.1016/j.jimonfin.2017.02.010

Boubaker, H., Cunado, J., Gil-Alana, L. A., \& Gupta, R. (2020). Global crises and gold as a safe haven: Evidence from over seven and a half centuries of data. Physica A: Statistical Mechanics and its Applications, 540, 123093. https://doi.org/10.1016/j.physa.2019.123093

Bulut, L., \& Rizvanoghlu, I. (2019). Is Gold a Safe Haven? International Evidence revisited. International Evidence Revisited (January 3, 2019). https://dx.doi.org/10.2139/ssrn.3344945

Chen, K., \& Wang, M. (2019). Is gold a hedge and safe haven for stock market?. Applied Economics Letters, 26(13), 1080-1086. https://doi.org/10.1080/13504851.2018.1537469

Ciner, C., Gurdgiev, C., \& Lucey, B. M. (2013). Hedges and safe havens: An examination of stocks, bonds, gold, oil and exchange rates. International Review of Financial Analysis, 29, 202-211. https://doi.org/10.1016/j.irfa.2012.12.001

Dee, J., Li, L., \& Zheng, Z. (2013). Is gold a hedge or a safe haven? Evidence from inflation and stock market. International Journal of Development and Sustainability, 2(1), 1-16.

Dickey, D., \& Fuller, W. A. (1979). Distribution of the estimators for time series regressions with a unit root. Journal of the American Statistical Association, 74(366), 427-431.

Flavin, T. J., Morley, C. E., \& Panopoulou, E. (2014). Identifying safe haven assets for equity investors through an analysis of the stability of shock transmission. Journal of International Financial Markets, Institutions and Money, 33, 137-154. https://doi.org/10.1016/j.intfin.2014.08.001

Ghazali, M. F., Lean, H. H., \& Bahari, Z. (2015). Sharia compliant gold investment in Malaysia: Hedge or safe haven?. Pacific-Basin Finance Journal, 34, 192-204. https://doi.org/10.1016/j.pacfin.2014.12.005

Gürgün, G., \& Ünalmış, İ. (2014). Is gold a safe haven against equity market investment in emerging and developing countries?. Finance Research Letters, 11(4), 341-348. https://doi.org/10.1016/j.frl.2014.07.003

Hartono, J. (2008). Teori portofolio dan analisis investasi. Yogyakarta: BPFE.

Hunt, D. A., Le Roux, C. L., \& Oberholzer, N. (2018). Precious metals as safe haven assets in the South African market.

International Monetary Fund (2019) World Economic Outlook. Global Manufacturing Downturn, Rising Trade Barriers. Available at: https://www.imf.org/en/Publications/WEO/Issues/2019/10/01/world-economic-outlookoctober-2019.

Kaul, A., \& Sapp, S. (2006). Y2K fears and safe haven trading of the US dollar. Journal of international money and finance, 25(5), 760-779. https://doi.org/10.1016/j.jimonfin.2006.04.003

Markowitz, H. (1952). Portfolio Selection The Journal of Finance, Vol. 7, No. 1.

Putra, M. P. S., Atahau, A. D. R., \& Robiyanto, R. (2018). Cross-asset class portfolio between gold and stocks in Indonesia. Economic Journal of Emerging Markets, 10(1), 69. https://doi.org/10.20885/ejem.vol10.iss1.art8

Ratnaningsih, N. M. D., \& Widanaputra, A. A. G. P. (2019). The reaction of Indonesian capital market to political event the announcement of Indonesia presidential election 2019 results. International research journal of management, IT and social sciences, 6(6), 87-94. https://doi.org/10.21744/irjmis.v6n6.765

Reboredo, J. C., \& Rivera-Castro, M. A. (2014). Gold and exchange rates: Downside risk and hedging at different investment horizons. International Review of Economics \& Finance, 34, 267-279. https://doi.org/10.1016/j.iref.2014.07.005

Robiyanto, R. (2017). Testing commodities as safe haven and hedging instrument on asean's five stock markets. Jurnal Ekonomi Kuantitatif Terapan, 10(2). 
Robiyanto, R. (2018). Testing of the Gold's Role as a Safe Haven and Hedge for Sharia Stocks in Indonesia. Al-Iqtishad Journal of Islamic Economics, 10(2), 255-266.

Wang, L. (2012). Investment in gold: An empirical study of the gold return from 90s to 21st. Copenhagen Business School, 90-100.

Pemayun, A. G. A. W., \& Yasa, G. W. (2020). Safe haven investment during turbulent conditions in Indonesia and Philippines capital market. International Research Journal of Management, IT and Social Sciences, 7(3), 137-143. https://doi.org/10.21744/irjmis.v7n3.934 